\title{
An Assessment of the Energy Generation Potential of Photovoltaic Systems in Cameroon Using Satellite-Derived Solar Radiation Datasets
}

\author{
Lacour Ayompe \\ Technological University Dublin, lacour.ayompe@tudublin.ie \\ Aidan Duffy \\ Technological University Dublin, aidan.duffy@tudublin.ie
}

Follow this and additional works at: https://arrow.tudublin.ie/aaconmusart

Part of the Natural Resource Economics Commons, Natural Resources and Conservation Commons, Natural Resources Management and Policy Commons, Oil, Gas, and Energy Commons, and the Sustainability Commons

\section{Recommended Citation}

Ayompe, L. and Duffy, A. (2014) An assessment of the energy generation potential of photovoltaic systems in Cameroon using satellite-derived solar radiation datasets, Sustainable Energy Technologies and Assessments, Volume 7, September 2014, Pages 257-264. doi:10.1016/j.seta.2013.10.002

This Article is brought to you for free and open access by the Conservatory of Music and Drama at ARROW@TU Dublin. It has been accepted for inclusion in Articles by an authorized administrator of ARROW@TU Dublin. For more information, please contact arrow.admin@tudublin.ie, aisling.coyne@tudublin.ie, gerard.connolly@tudublin.ie.

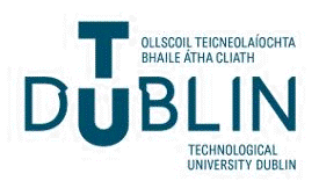




\section{AUTHOR QUERY FORM}

\begin{tabular}{|l|l|l|}
\hline & Journal: SETA & Please e-mail or fax your responses and any corrections to: \\
& & E-mail: corrections.esch@elsevier.sps.co.in \\
\hline ELSEVIER & Article Number: 33 & Fax: +31204852799 \\
\hline
\end{tabular}

Dear Author,

Please check your proof carefully and mark all corrections at the appropriate place in the proof (e.g., by using on-screen annotation in the PDF file) or compile them in a separate list. Note: if you opt to annotate the file with software other than Adobe Reader then please also highlight the appropriate place in the PDF file. To ensure fast publication of your paper please return your corrections within 48 hours.

For correction or revision of any artwork, please consult http://www.elsevier.com/artworkinstructions.

Any queries or remarks that have arisen during the processing of your manuscript are listed below and highlighted by flags in the proof. Click on the ' $Q$ ' link to go to the location in the proof.

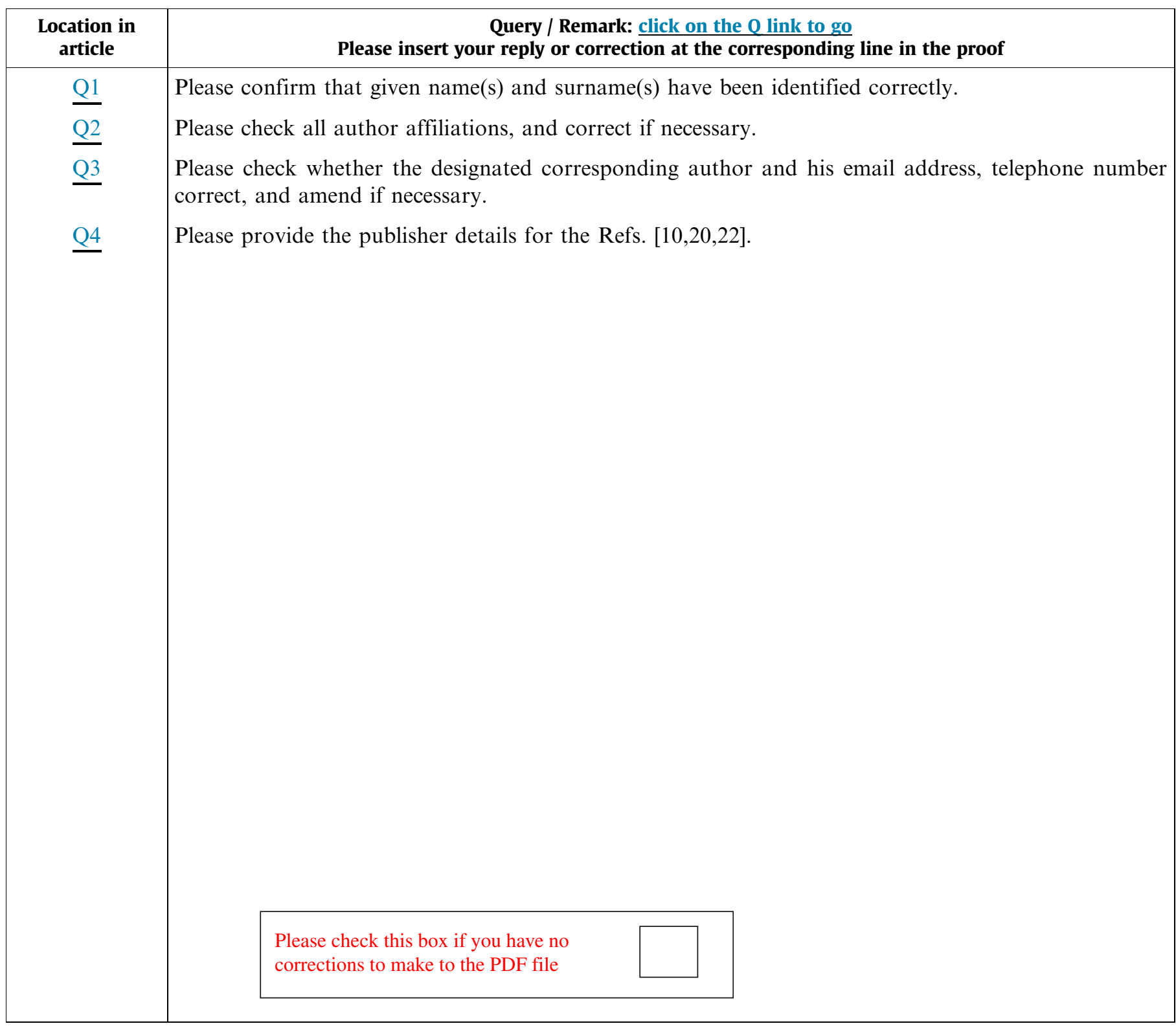

Thank you for your assistance. 


\title{
An assessment of the energy generation potential of photovoltaic systems in Cameroon using satellite-derived solar radiation datasets
}

\author{
8 Q1 L.M. Ayompe* $e_{\curlywedge}^{*}$ A. Duffy \\ Q2 School of Civil E Building Services Engineering, Dublin Energy Lab, Dublin Institute of Technology, Dublin 1, Ireland
}

\section{A R T I C L E I N F O}

\section{Article history:}

Received 25 January 2013

Revised 28 September 2013

Accepted 7 October 2013

Available online $\mathrm{xxxx}$

\section{Keywords:}

Photovoltaic system

Solar irradiation datasets

Energy output

Simple payback period

Levelised cost of electricity

\begin{abstract}
A B S T R A C T
Cameroon like most developing countries does not have a reliable network of surface observation stations for collecting weather data. This has been a major drawback for accurate assessment of the energy generation potential of photovoltaic systems in Cameroon. A viable alternative is to obtain site-specific solar irradiation from satellite-derived datasets. In this paper, the energy output, capacity factor and performance ratio of photovoltaic systems in 33 locations spread around ten regions in Cameroon have been evaluated using monthly average daily global horizontal solar irradiation from long-term satellitederived data available in Solar GIS software.

An economic assessment revealed that a simple payback period of 5.6 years and levelised cost of electricity generation of $6.79 € \mathrm{c} / \mathrm{kWh}$ can be achieved in locations with annual electricity generation of $1764 \mathrm{kWh} / \mathrm{kW}_{\mathrm{p}}$ if the capital cost of the PV system is $1500 € / \mathrm{kW}_{\mathrm{p}}$ at a discount rate of $5 \%$. Alternatively, the simple payback period would be 15.7 years and the levelised cost of electricity generation $28.82 \mathrm{€c} /$ $\mathrm{kWh}$ if the capital cost is $2500 € / \mathrm{kW}_{\mathrm{p}}$ at a discount rate of $10 \%$ in locations with annual electricity generation of $1053 \mathrm{kWh} / \mathrm{kW}_{\mathrm{p}}$
\end{abstract}

다 2013 Published by Elsevier Ltd.

\section{Introduction}

Cameroon is a Sub-Saharan country covering a total surface area of $475,440 \mathrm{~km}^{2}$. It is located at latitude $6^{\circ} 0^{\prime} 0^{\prime \prime} \mathrm{N}$ and longitude $12^{\circ} 0^{\prime} 0^{\prime \prime} \mathrm{E}$ with parts in the central and western parts of Africa. Its population was estimated at 20.1 million in July 2012 with an annual growth rate of $2.1 \% .58 \%$ of its population lives in urban areas and the annual urbanisation growth rate is 3.3\%. There are ten regions in Cameroon with Yaoundé and Douala the largest cities having 1.74 and 2.05 million inhabitants, respectively [1].

The electricity sector in Cameroon is facing both structural and technical difficulties. Out of over 14,000 localities, about 3000 are electrified resulting in a national electrification rate of $22 \%$ while the rate of rural electrification is $3.5 \%$. The low rate of electrification has been a major handicap to the production of goods and services [2]. The Government of Cameroon has outlined plans to address this issue in its development vision up to 2035 which aims at reducing poverty and transforming it into an emerging country. Upgrading its energy infrastructure is a key requirement to the achievement of this objective [3].

Increase in global fossil fuel prices have resulted in a rise in the retail price of electricity in Cameroon. Between 2008 and 2012, retail electricity prices increased by an annual average of $4.0 \%$.

\footnotetext{
* Corresponding author. Tel.: +353 857786815 .

E-mail address: lacour.ayompe@dit.ie (L.M. Ayompe).
}

Therefore, there is a need to explore other energy resources such as renewable energy sources (RES) with low environmental impact.

RES in Cameroon include biomass, solar energy, hydro power, geothermal energy, wind and tidal energy. Despite the availability of a variety of RES only hydro power has been widely exploited for electricity generation. Abanda [4] reported that very little research has been undertaken to evaluate the potential of RES in Cameroon. Literature on different types of RES, their benefits and market potential is therefore very limited or non-existent resulting in an information gap for researchers, potential investors and policy makers. He therefore recommended that there is a need to scaleup research in the development of RES in Cameroon in order to provide information required for evidence-based energy policy formulation that would encourage their adoption in the country's energy mix.

Cameroon is endowed with vast solar energy potential with about 900 trillion kWh of solar energy reaching its land area per annum. Tchinda and Kaptouom [5] reported that the Northern and Southern regions of Cameroon received between 4.00 and $5.80 \mathrm{kWh} / \mathrm{m}^{2} \mathrm{~d}$ while Tansi [6] reported that Southern regions typically receive $4.90 \mathrm{kWh} / \mathrm{m}^{2} \mathrm{~d}$. Photovoltaic technologies can be employed to harneŝे this enêrgy and generate power on both a centralized and distributed basis. PV systems are scalable so they can either be used to generate electricity for on-site use in 
domestic dwellings and commercial buildings or exported to the national grid.

\section{Electricity market}

In 2010, AES-SONEL an integrated utility company operated $925 \mathrm{MW}$ of generation capacity, three transmission networks and distributed electricity to approximately 700,000 customers under a 20-year concession agreement that was signed in July 2001. It has exclusive distribution rights to all medium voltage and low voltage customers, except for customers with an installed capacity of more than $1 \mathrm{MW}$ ("Major Customers") who are free to negotiate bilateral agreements. Electricity generation in Cameroon is open to competition and independent power producers (IPPs) are authorised to generate and sell electricity to AES-SONEL under a power purchase agreement [7].

AES-SONEL operates three transmission grids: the southern interconnected grid (SIG); northern interconnected grid (NIG); and eastern isolated grid (EIG) through which all electricity generated is transmitted for distribution to its customers. Fig. 1 shows the electric power demand, installed and available capacity in the SIG, NIG and EIG in 2010 in Cameroon. The total electric power installed capacity was $1505 \mathrm{MW}$ of which 1242 was available while the demand was $7 \hat{3} 6 \mathrm{MW}$. The SIG had the highest electric power demand, installed and available capacity of 654, 1321 and $1090 \mathrm{MW}$, respectively followed by the NIG and EIG. The national grid is discontinuous thereby preventing the transfer of electricity between the three grids.

In 2010, the installed capacity of hydroelectric power plants in Cameroon was $729 \mathrm{MW}$ (48.4\%) of which $620 \mathrm{MW}$ was available for use as shown in Table 1 Thermal power plants (natural gas and diesel) owned by both AES-SONEL and IPPs had an installed $n \quad$ operating year

OPEX operation and maintenance cost $(€)$

PR performance ratio (dimensionless)

$P_{\mathrm{PV} \text {,rated }}$ installed PV system capacity (kW)

$\eta_{\text {STC }} \quad$ PV module efficiency (as a fraction) under STC (dimensionless). capacity of $776 \mathrm{MW}$ (51.6\%) of which $622 \mathrm{MW}$ was available. There was no other type of renewable energy technology used in electric power generation in Cameroon in 2010.

\section{Planned investments}

Demand for electricity in Cameroon is estimated to reach $1455 \mathrm{MW}$ in 2014 and almost $5000 \mathrm{MW}$ in 2020 taking into consideration the unmet demand due to the low rate of electrification and access to the electricity grid as well as the needs of major industrial projects required to transform the country's economy. Greenhouse gas (GHG) emissions associated with electricity generation in Cameroon was estimated at $0.86 \mathrm{tCO}_{2} / \mathrm{MW}$ compared to the global average of $0.57 \mathrm{tCO}_{2} / \mathrm{MW}$ [2]. This high carbon intensity is as a result of the use of thermal plants based on diesel and heavy oils.

In order to meet the projected increase in domestic electricity demand and that of neighbouring countries while reducing its GHG emissions, the government of Cameroon prepared an Electricity Sector Development Plan (ESDP) up to 2030. The Plan involves ensuring consistency in the development of electricity supply and demand in the context of the country's economic growth. The plan for the development of power generating plants consists of installing about $2500 \mathrm{MW}$ of hydroelectric power between 2012 and 2020 and $2 \hat{9} 8 \mathrm{MW}$ of electricity from thermal plants between 2010 and 2013.

Recently, the government of Cameroon recognised photovoltaics (PV) as a viable source of electricity generation. In July 2012 , it signed a memorandum of understanding with a private developer to finance, develop, build and operate $500 \mathrm{MW}$ of grid connected and stand-alone solar photovoltaic systems between 2012 and 2020. The first phase of this project consisting of $100 \mathrm{MW}$ of

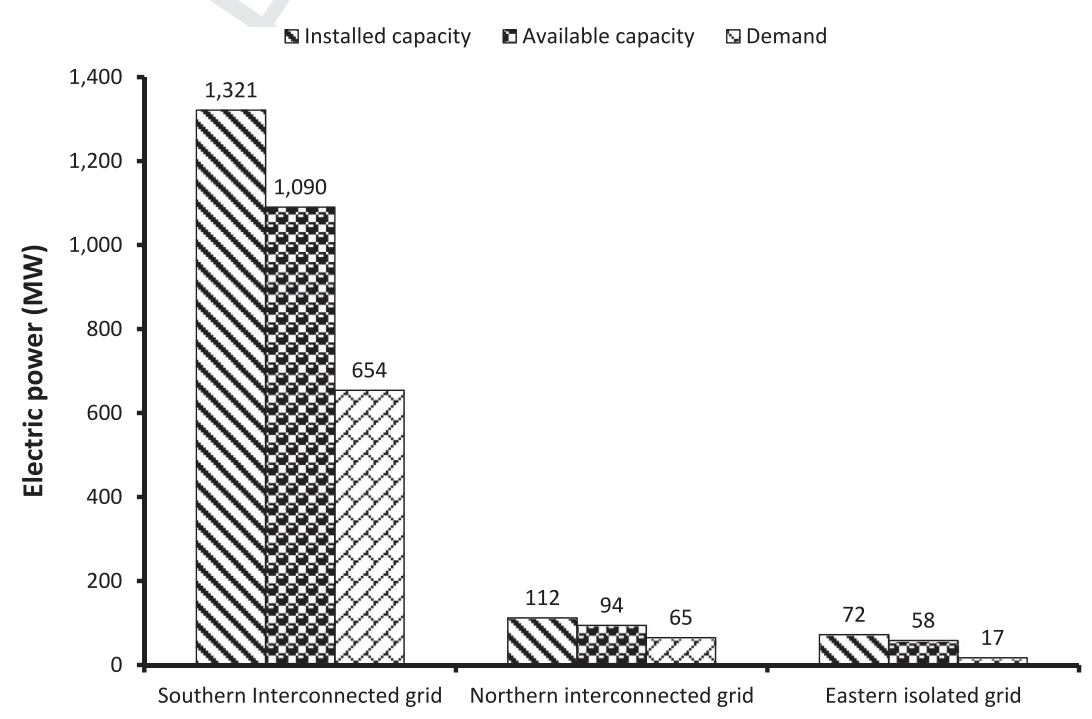

Fig. 1. Installed capacity, available capacity and demand of electric power in 2010 in Cameroon. 
Table 1

Installed and available capacity (MW) of electric power plants in Cameroon in 2010 [2].

\begin{tabular}{|c|c|c|c|c|c|c|c|c|c|}
\hline \multirow{2}{*}{$\begin{array}{l}\text { Plant } \\
\text { Type }\end{array}$} & \multirow[t]{2}{*}{ Owner } & \multicolumn{2}{|c|}{ Southern interconnected grid } & \multicolumn{2}{|c|}{ Northern interconnected grid } & \multicolumn{2}{|c|}{ Eastern isolated grid } & \multicolumn{2}{|l|}{ Total } \\
\hline & & $\begin{array}{l}\text { Installed } \\
\text { capacity }\end{array}$ & $\begin{array}{l}\text { Available } \\
\text { capacity }\end{array}$ & $\begin{array}{l}\text { Installed } \\
\text { capacity }\end{array}$ & $\begin{array}{l}\text { Available } \\
\text { Capacity }\end{array}$ & $\begin{array}{l}\text { Installed } \\
\text { capacity }\end{array}$ & $\begin{array}{l}\text { Available } \\
\text { capacity }\end{array}$ & $\begin{array}{l}\text { Installed } \\
\text { capacity }\end{array}$ & $\begin{array}{l}\text { Available } \\
\text { capacity }\end{array}$ \\
\hline Thermal & AES-SONEL & 268 & 214 & 19 & 16 & 12 & 10 & 299 & 240 \\
\hline Thermal & IPP & 396 & 317 & 21 & 17 & 60 & 48 & 477 & 382 \\
\hline Hydro & AES-SONEL & 657 & 559 & 72 & 61 & 0 & 0 & 729 & 620 \\
\hline \multicolumn{2}{|c|}{ Total } & 1321 & 1090 & 112 & 94 & 72 & 58 & 1505 & 1242 \\
\hline \multicolumn{2}{|c|}{ Percentage of hydro } & 49.7 & 51.3 & 64.3 & 64.9 & 0.0 & 0.0 & 48.4 & 49.9 \\
\hline \multicolumn{2}{|c|}{ Demand } & & 654 & & 65 & & 17 & & \\
\hline
\end{tabular}

grid connected PV systems was due to commence in October 2012. It is expected that these systems would generate $145,000 \mathrm{MW}_{\mathrm{A}}$ of electricity annually.

\section{Rationale for PV}

From the above, it is seen that despite the enormous solar energy potential available in Cameroon, government policies towards increasing the quantity of electricity generation have largely been in favour of hydro and thermal power plants. Considering that the two main hydroelectric plants in Edea and Song Loulou with installed capacities of 263 and $394 \mathrm{MW}$ had underperformed due to extended droughts between 2000 and 2003 which resulted in load shedding, it is imperative that Cameroon cannot rely to a large extent on its hydro potential. Thermal plants emit large quantities of GHGs and are subject to fossil fuel price fluctuations. Similarly, continuous increase in the cost of fossil fuels would result in an increase in the cost of electricity generation from thermal plants while emitting GHGs.

Electricity generation using PV systems on the other hand uses solar energy which is free and not prone to price fluctuations. PV systems generate electricity with no GHG emissions, so they would contribute towards reducing the $\mathrm{CO}_{2}$ intensity of electricity generation in Cameroon. Solar radiation in most parts of Cameroon is highest during the dry season when water levels are low and electricity generation using hydro power plants is at its minimum. It therefore has the potential to mitigate the impact of reduced electricity generation from hydro power plants during the dry season. Also, the electricity generation profile from PV systems would suit the consumption profile in most commercial buildings.

Photovoltaic systems have large initial capital cost but small recurrent costs for operation and maintenance. The price of delivered energy varies inversely to the lifetime of the system. Proven technologies such as silicon-based modules exhibit lifetimes of 20 -30 years or more [8]. Over the years, the cost of PV modules have decreased at a learning rate of $15-22 \%$ [9] and have seen a corresponding reduction in total system costs for every doubling of cumulative installed capacity. The European Photovoltaic Industry Association (EPIA) [10] estimates that the cost of electricity generated from PV systems would become competitive with grid supplied electricity in some sunny climates with similar solar insolation as Cameroon by 2015. The actual period when this parity occurs depends on the cost of PV systems in different countries as well as support policies in place.

\section{Methodology}

It is evident that Cameroon has to diversify its energy mix in electricity generation in order to satisfy future demand while reducing its GHG emissions. Exploiting RES such as solar energy using PV systems is therefore imperative. This paper therefore assesses the energy generation potential of PV systems with crystalline silicon (c-Si), amorphous silicon (a-Si) and cupper indium selenide (CIS) PV modules in different locations in Cameroon.

With no reliable ground measurements in Cameroon, the paper compares ground measurements of monthly average daily global horizontal irradiation (GHI) for 22 cities in six neighbouring countries against satellite-derived data from three commercially available softwares. The best dataset for locations in Cameroon was selected as that with the lowest root mean square error. Energy output prediction from Solar GIS pvPlanner software [11] was validated using measured performance data for a PV system. The software was then used to evaluate the energy generated by PV systems with optimally inclined PV modules.

An economic analysis was undertaken to evaluate the conditions under which investment in PV systems would be viable in Cameroon. Simple payback periods and levelised costs of electricity generation were computed for a range of capital costs, discount rates, normalised annual electricity generation and electricity tariff for consumers with annual electricity demand exceeding $800 \mathrm{kWh}$.

\section{Solar resource}

It has long been understood that high-quality time-series solar irradiation data is crucial to the successful design and deployment of solar energy systems since it is the variable which has the greatest impact on electrical power output [12]. Site-specific climatic data is important since design details and economic feasibility are a direct function of variables such as the local solar resource, in both magnitude (high irradiance) and quality (low variability and high predictability) [13]. The key variable for fixed panel PV systems is global horizontal irradiance (GHI), or the amount of radiation received by a horizontal surface.

Little research has been carried out to measure solar irradiation in different locations in Cameroon. Njomo [14] measured solar irradiation in ten meteorological stations in Cameroon between 1982 and 1987. In another study Njomo and Wald [15] compared ground measurements for Yaoundé and Garoua against satellitederived solar irradiation using the Heliosat_2 method. Their analysis showed that there was good agreement between the measured and satellite-derived data for Garoua (with semi-arid surface and uniformly dry atmosphere) while there was large variability in Yaoundé (forest type surface with a humid and persistently cloudy atmosphere).

It is therefore evident that data obtained from ground measurements in Cameroon is either non-existent or available for short intervals and unreliable because of maintenance issues with malfunctioning devices which were poorly attended. In such cases, calculating site-specific solar irradiance values using satellite-derived data has become an accepted alternative. Within the global atmospheric science community, satellite-derived values have proven to be more accurate than nearby surface observations for locations that are more than $25 \mathrm{~km}$ away from a well-maintained ground station. However, there exists a number of satellite-derived solar 
Table 2

Annual average daily wind speed, ambient air temperature and GHI for different locations in Cameroon [11].

\begin{tabular}{|c|c|c|c|c|c|c|c|}
\hline Location & Region & Latitude $\left(^{\circ}\right)$ & Longitude $\left({ }^{\circ}\right)$ & Elevation (m) & Wind speed $(\mathrm{m} / \mathrm{s})$ & $\begin{array}{l}\text { Ambient air } \\
\text { temperature }\left({ }^{\circ} \mathrm{C}\right)\end{array}$ & $\begin{array}{l}\text { Annual average daily } \\
\text { GHI }\left(\mathrm{kWh} / \mathrm{m}^{2} \mathrm{~d}\right)\end{array}$ \\
\hline Banyo & Adamawa & 6.8 & 11.8 & 1,123 & 2.8 & 21.3 & 5.82 \\
\hline Meiganga & Adamawa & 6.5 & 14.3 & 990 & 3.2 & 23.1 & 5.76 \\
\hline Ngoundéré & Adamawa & 7.3 & 13.6 & 1162 & 3.3 & 21.5 & 5.77 \\
\hline Tibati & Adamawa & 6.5 & 12.6 & 332 & 3.2 & 23.6 & 5.78 \\
\hline Akonolinga & Centre & 3.8 & 12.3 & 634 & 1.4 & 23.0 & 4.94 \\
\hline Bafia & Centre & 4.8 & 11.2 & 517 & 1.8 & 24.4 & 5.22 \\
\hline Abong Mbang & East & 4.0 & 13.2 & 693 & 1.5 & 22.9 & 4.94 \\
\hline Batouri & East & 4.4 & 14.4 & 637 & 2.0 & 24.4 & 5.27 \\
\hline Bertoua & East & 4.6 & 13.7 & 661 & 1.9 & 23.6 & 5.18 \\
\hline Yokadouma & East & 3.5 & 15.1 & 566 & 1.7 & 24.0 & 5.20 \\
\hline Maroua & Far North & 10.6 & 14.3 & 404 & 3.8 & 28.8 & 5.99 \\
\hline Mokolo & Far North & 10.8 & 13.8 & 432 & 3.7 & 24.0 & 5.92 \\
\hline Mora & Far North & 11.0 & 14.1 & 608 & 3.9 & 26.1 & 5.99 \\
\hline Yagoua & Far North & 10.4 & 15.2 & 322 & 3.9 & 28.9 & 5.97 \\
\hline Douala & Littoral & 4.1 & 9.7 & 11 & 1.8 & 26.2 & 4.76 \\
\hline Edea & Littoral & 3.8 & 10.1 & 31 & 1.5 & 25.7 & 4.71 \\
\hline Garoua & North & 9.3 & 13.4 & 185 & 3.5 & 29.3 & 5.81 \\
\hline Garoua Boulai & North & 5.9 & 14.6 & 1002 & 2.8 & 22.9 & 5.62 \\
\hline Tcholliré & North & 8.4 & 14.2 & 332 & 3.4 & 26.2 & 5.81 \\
\hline Bamenda & North West & 6.0 & 10.2 & 1255 & 1.9 & 18.7 & 5.36 \\
\hline Kumbo & North West & 6.2 & 10.7 & 1739 & 2.3 & 17.5 & 5.55 \\
\hline Wum & North West & 6.4 & 10.1 & 1034 & 2.3 & 21.0 & 5.32 \\
\hline Akom & South & 2.8 & 10.6 & 316 & 1.5 & 22.3 & 4.72 \\
\hline Ebolowa & South & 2.9 & 11.1 & 591 & 1.4 & 22.3 & 4.84 \\
\hline Kribi & South & 2.9 & 9.9 & 20 & 1.8 & 25.4 & 4.85 \\
\hline Buea & South West & 4.2 & 9.2 & 984 & 1.8 & 22.1 & 4.00 \\
\hline Fontem & South West & 5.5 & 9.9 & 1046 & 1.8 & 20.2 & 4.35 \\
\hline Kumba & South West & 4.6 & 9.5 & 226 & 1.8 & 25.2 & 4.85 \\
\hline Mamfe & South West & 5.8 & 9.3 & 88 & 1.8 & 24.8 & 4.96 \\
\hline Mundemba & South West & 5.0 & 8.9 & 147 & 2.2 & 26.2 & 4.40 \\
\hline Muyuka & South West & 4.3 & 9.4 & 47 & 1.8 & 25.5 & 4.73 \\
\hline Nguti & South West & 5.3 & 9.4 & 231 & 1.8 & 23.1 & 4.94 \\
\hline Baffousam & West & 5.5 & 10.4 & 1384 & 1.9 & 19.1 & 5.63 \\
\hline
\end{tabular}

radiation datasets that provide estimates for different locations in Cameroon. Selecting the most suitable dataset is important for energy output assessment from PV systems.

In order to choose the best dataset for locations in Cameroon, a comparison of ground measurements of average daily global horizontal irradiation for 22 cities in Burkina Faso (5), Ghana (6), Guinea (2), Mauritania (3), Nigeria (3) and Senegal (3) against satellite-derived solar radiation datasets from three commercially available software which include: Solar GIS, Solar radiation data (SoDa), National Aeronautics and Space Administration (NASA) was undertaken. The results showed that the mean bias errors (MBE) were $2.5 \%, 2.7 \%$ and $-6.7 \%$ while the root mean square errors (RMSE) were $7.9 \%, 9.3 \%$ and $13.1 \%$ for Solar GIS, NASA and SoDa datasets, respectively. The Solar GIS dataset [11] was chosen as the best because it had the lowest MBE and RMSE. The positive MBE shows that it overestimates with maximum average deviation of $7.9 \%$. Predicted PV energy outputs used in the economic analysis were therefore reduced by $7.9 \%$.

Table 2 shows satellite-derived annual average daily GHI available in Solar GIS for different locations in Cameroon. Solar irradiation varies between $4.00 \mathrm{kWh} / \mathrm{m}^{2} \mathrm{~d}$ in Buea (South West Region) and $5.99 \mathrm{kWh} / \mathrm{m}^{2} \mathrm{~d}$ in Mâroua and Mora (Far North Region). The lowest average annual wind speed is $1.4 \mathrm{~m} / \mathrm{s}$ in Akonolinga (Center Region) and Ebolowa (South Region) while the highest average annual wind speed is $3.9 \mathrm{~m} / \mathrm{s}$ in Mora and Yagoua (Far North Region). The annual average ambient air temperature varies between $17.5^{\circ} \mathrm{C}$ in Kumbo (North West Region) and $29.3^{\circ} \mathrm{C}$ in Garoua (North Region).

\section{Energy performance of PV systems}

In order to analyse the energy-related performance of PV systems, some important parameters must be computed using weather data for the location of interest. Some of these parameters include: the total AC energy generated by the PV system $\left(E_{\mathrm{AC}}\right)$; the performance ratio (PR) and the capacity factor (CF). These normalised performance indicators are relevant since they provide a basis under which PV systems can be compared under various operating conditions.

Table 3 shows the optimum inclination of PV modules; annual average daily GHI; global irradiation on the surface of the PV modules; average daily energy output, PR and CF for c-Si, a-Si and CIS PV modules. It is seen that optimally inclined PV modules receive more irradiation than those on horizontal surfaces. The lowest optimum inclination angle is $5^{\circ}$ in the South Region while the highest is $15-16^{\circ}$ in the Far North Region.

\section{Energy output assessment}

Predicting the energy output from a PV system is a matter of combining the characteristics of the major components, that is, the PV array and the inverter with local insolation and temperature data. Energy output prediction using Solar GIS's pvPlanner tool was validated using measured data reported in Ayompe et al. [16]. The pvPlanner tool was therefore used to model the energy output from the PV systems assuming: 95\% inverter euro efficiency, 5.5\% DC losses, 1.5\% AC losses and 99\% availability.

It is seen in Table 3 that the energy output is highest for a-Si followed by CIS and c-Si PV modules for all the locations considered in this study. The average daily energy output has lowest values of $3.13,3.28$ and $3.15 \mathrm{kWh} / \mathrm{kW}_{\mathrm{p}}$ in Buea (South West Region) and highest valuês of $4.74,5.25$ and $4.74 \mathrm{kWh} / \mathrm{kW}_{\mathrm{p}}$ in Mora (Far North Region) for c-Si, a-Si and CISPV modûtes, respectively. These would result in annual energy output ranging between 1143 and $1916 \mathrm{kWh} / \mathrm{kW}_{\mathrm{p}}$. Considering that the Solar GIS dataset overestimates average daily GHI by an average of $7.9 \%$, the energy output range was reduced to 1053 and $1764 \mathrm{kWh} / \mathrm{kW}_{\mathrm{p}}$. The economic 
Table 3

Annual average daily energy output, performance ratio and capacity factor for PV module technologies in different locations in Cameroon.

\begin{tabular}{|c|c|c|c|c|c|c|c|c|c|c|c|c|c|}
\hline \multirow[t]{2}{*}{ Location } & \multirow[t]{2}{*}{ Region } & \multirow[t]{2}{*}{$\begin{array}{l}\text { Optimum } \\
\text { inclination }\left({ }^{\circ}\right)\end{array}$} & \multirow[t]{2}{*}{$\begin{array}{l}\text { Solar GIS annual average } \\
\text { daily GHI }\left(\mathrm{kWh} / \mathrm{m}^{2} \mathrm{~d}\right)\end{array}$} & \multirow[t]{2}{*}{$\begin{array}{l}\text { Global radiation on PV } \\
\text { surface }\left(\mathrm{kWh} / \mathrm{m}^{2} \mathrm{~d}\right)\end{array}$} & \multicolumn{3}{|c|}{$\begin{array}{l}\text { Energy output } \\
\left(\mathrm{kWh} / \mathrm{kW}_{\mathrm{p}}\right)\end{array}$} & \multicolumn{3}{|c|}{$\begin{array}{l}\text { Performance ratio } \\
(\%)\end{array}$} & \multicolumn{3}{|c|}{ Capacity factor (\%) } \\
\hline & & & & & c-Si & $\mathrm{a}-\mathrm{Si}$ & CIS & $\mathrm{c}-\mathrm{Si}$ & $\mathrm{a}-\mathrm{Si}$ & CIS & $\mathrm{c}-\mathrm{Si}$ & $\mathrm{a}-\mathrm{Si}$ & CIS \\
\hline Banyo & Adamawa & 11 & 5.82 & 5.92 & 4.56 & 5.05 & 4.65 & 77.0 & 85.4 & 78.5 & 19.0 & 21.1 & 19.4 \\
\hline Meiganga & Adamawa & 11 & 5.76 & 5.86 & 4.47 & 4.99 & 4.56 & 76.2 & 85.1 & 77.8 & 18.6 & 20.8 & 19.0 \\
\hline Ngoundéré & Adamawa & 13 & 5.77 & 5.90 & 4.54 & 5.03 & 4.63 & 77.0 & 85.3 & 78.4 & 18.9 & 21.0 & 19.3 \\
\hline Tibati & Adamawa & 11 & 5.78 & 5.79 & 4.46 & 5.00 & 4.56 & 76.0 & 85.1 & 77.6 & 18.6 & 20.8 & 19.0 \\
\hline Akonolinga & Centre & 6 & 4.94 & 4.97 & 3.83 & 4.20 & 3.88 & 77.1 & 84.5 & 78.2 & 16.0 & 17.5 & 16.2 \\
\hline Bafia & Centre & 7 & 5.22 & 5.26 & 4.03 & 4.45 & 4.10 & 76.7 & 84.7 & 77.9 & 16.8 & 18.6 & 17.1 \\
\hline $\begin{array}{l}\text { Abong } \\
\text { Mbang }\end{array}$ & East & 7 & 4.94 & 4.97 & 3.83 & 4.20 & 3.89 & 77.1 & 84.5 & 78.2 & 16.0 & 17.5 & 16.2 \\
\hline Batouri & East & 7 & 5.27 & 5.31 & 4.06 & 4.51 & 4.13 & 76.4 & 84.9 & 77.8 & 16.9 & 18.8 & 17.2 \\
\hline Bertoua & East & 8 & 5.18 & 5.22 & 4.01 & 4.43 & 4.08 & 76.8 & 84.8 & 78.0 & 16.7 & 18.5 & 17.0 \\
\hline Yokadouma & East & 6 & 5.20 & 5.23 & 4.00 & 4.44 & 4.07 & 76.6 & 84.9 & 77.9 & 16.7 & 18.5 & 17.0 \\
\hline Maroua & Far North & 15 & 5.99 & 6.17 & 4.59 & 5.20 & 4.71 & 74.4 & 84.3 & 76.3 & 19.1 & 21.7 & 19.6 \\
\hline Mokolo & Far North & 15 & 5.92 & 6.10 & 4.61 & 5.20 & 4.72 & 74.0 & 83.5 & 75.8 & 19.2 & 21.7 & 19.6 \\
\hline Mora & Far North & 16 & 5.99 & 6.19 & 4.74 & 5.25 & 4.74 & 74.6 & 84.5 & 76.5 & 19.7 & 21.9 & 19.7 \\
\hline Yagoua & Far North & 15 & 5.97 & 6.14 & 4.57 & 5.18 & 4.68 & 74.3 & 84.2 & 76.2 & 19.0 & 21.6 & 19.5 \\
\hline Douala & Littoral & 6 & 4.76 & 4.78 & 3.64 & 4.02 & 3.70 & 76.1 & 84.1 & 77.3 & 15.2 & 16.8 & 15.4 \\
\hline Edea & Littoral & 6 & 4.71 & 4.73 & 3.63 & 3.97 & 3.68 & 76.6 & 83.8 & 77.7 & 15.1 & 16.5 & 15.3 \\
\hline Garoua & North & 13 & 5.81 & 5.96 & 4.42 & 5.01 & 4.53 & 74.1 & 84.0 & 76.0 & 18.4 & 20.9 & 18.9 \\
\hline $\begin{array}{l}\text { Garoua } \\
\text { Boulai }\end{array}$ & North & 10 & 5.62 & 5.62 & 4.36 & 4.84 & 4.44 & 76.4 & 84.9 & 77.9 & 18.2 & 20.2 & 18.5 \\
\hline Tcholliré & North & 13 & 5.81 & 5.94 & 4.43 & 5.01 & 4.54 & 74.6 & 84.3 & 76.4 & 18.5 & 20.9 & 18.9 \\
\hline Bamenda & $\begin{array}{l}\text { North } \\
\text { West }\end{array}$ & 10 & 5.36 & 5.44 & 4.25 & 4.59 & 4.34 & 78.2 & 84.4 & 79.4 & 17.7 & 19.1 & 18.1 \\
\hline Kumbo & $\begin{array}{l}\text { North } \\
\text { West }\end{array}$ & 11 & 5.55 & 5.64 & 4.43 & 4.78 & 4.49 & 78.8 & 84.7 & 79.7 & 18.5 & 19.9 & 18.7 \\
\hline Wum & $\begin{array}{l}\text { North } \\
\text { West }\end{array}$ & 11 & 5.32 & 5.40 & 4.18 & 4.57 & 4.25 & 77.5 & 84.8 & 78.8 & 17.4 & 19.1 & 17.7 \\
\hline Akom & South & 5 & 4.72 & 4.74 & 3.69 & 3.98 & 3.73 & 77.8 & 83.8 & 78.8 & 15.4 & 16.6 & 15.6 \\
\hline Ebolowa & South & 5 & 4.84 & 4.85 & 3.78 & 4.08 & 3.82 & 77.8 & 84.1 & 78.8 & 15.7 & 17.0 & 15.9 \\
\hline Kribi & South & 5 & 4.85 & 4.87 & 3.75 & 4.10 & 3.80 & 76.9 & 84.2 & 78.0 & 15.6 & 17.1 & 15.8 \\
\hline Buea & $\begin{array}{l}\text { South } \\
\text { West }\end{array}$ & 6 & 4.00 & 4.01 & 3.13 & 3.28 & 3.15 & 77.8 & 81.4 & 78.3 & 13.1 & 13.1 & 13.1 \\
\hline Fontem & $\begin{array}{l}\text { South } \\
\text { West }\end{array}$ & 10 & 4.35 & 4.39 & 3.46 & 3.62 & 3.46 & 78.6 & 82.2 & 78.6 & 14.4 & 15.1 & 14.4 \\
\hline Kumba & $\begin{array}{l}\text { South } \\
\text { West }\end{array}$ & 6 & 4.85 & 4.87 & 3.73 & 4.11 & 3.78 & 76.5 & 84.4 & 77.7 & 15.5 & 17.1 & 15.8 \\
\hline Mamfe & $\begin{array}{l}\text { South } \\
\text { West }\end{array}$ & 8 & 4.96 & 5.00 & 3.82 & 4.22 & 3.88 & 76.4 & 84.4 & 77.6 & 15.9 & 17.6 & 16.2 \\
\hline Mundemba & $\begin{array}{l}\text { South } \\
\text { West }\end{array}$ & 7 & 4.40 & 4.42 & 3.37 & 3.71 & 3.41 & 76.1 & 83.9 & 77.1 & 14.0 & 15.5 & 14.2 \\
\hline Muyuka & $\begin{array}{l}\text { South } \\
\text { West }\end{array}$ & 6 & 4.73 & 4.75 & 3.65 & 3.98 & 3.69 & 76.8 & 83.9 & 77.8 & 15.2 & 16.6 & 15.4 \\
\hline Nguti & $\begin{array}{l}\text { South } \\
\text { West }\end{array}$ & 8 & 4.94 & 4.97 & 3.84 & 4.21 & 3.90 & 77.2 & 84.5 & 78.4 & 16.0 & 17.5 & 16.2 \\
\hline Baffousam & West & 9 & 5.63 & 5.69 & 4.46 & 4.83 & 4.53 & 78.2 & 84.8 & 79.5 & 18.6 & 20.1 & 18.9 \\
\hline
\end{tabular}

analysis undertaken in this paper therefore considered annual electricity generation between 1053 and $1764 \mathrm{kWh} / \mathrm{kW}_{\mathrm{p}}$.

\section{Performance ratio}

The performance ratio (PR) indicates the overall effect of losses on a PV array's normal power output and depends on its temperature, incomplete utilisation of incident solar radiation and system component inefficiencies or failures. The PR of a PV system indicates how close it approaches ideal performance during real operation and allows comparison of PV systems independent of location, tilt angle, orientation and their nominal rated power capacity $[17,18]$. Performance ratio is defined by the following equation $[19,20]$ :

$\mathrm{PR}=\frac{E_{\mathrm{AC}}}{G_{m} \eta_{\mathrm{STC}}}$

It is seen in Table 3 that the PR for c-Si PV modules varied between $74.0 \%$ in Mokolo (Far North Region) and 78.8\% in Kumbo
(North West Region). For a-Si PV modules, the PR varied between $81.4 \%$ in Buea (South West Region) and $85.4 \%$ in Banyo (Adamawa Region) while for CIS PV modules the PR varied between $75.8 \%$ in Mokolo (Far North Region) and 79.7\% in Kumbo (North West Region). It is seen that c-Si and CIS PV modules have higher PR in locations with low annual average ambient air temperature because of their negative temperature coefficient. c-Si PV modules have higher temperature coefficients than CIS PV modules so this results in lower PR under high ambient temperatures. a-Si has the highest PR in all locations due to their low temperature coefficient compared to that of c-Si and CIS PV modules.

\section{Capacity factor}

The capacity factor (CF) or capacity utilisation factor (CUF) is a means used to present the energy delivered by an electric power generating system. If the system delivers full rated power continuously, its CF would be unity. CF is defined as the ratio of the actual annual energy output to the amount of energy the PV system would generate if it operated at full rated power $\left(P_{\mathrm{PV} \text {,rated }}\right)$ for 24 $\mathrm{h}$ per day for a year and is given as [21]: 
Table 3 shows that the CF for c-Si, a-Si and CIS PV modules had lowest values of $13.1 \%, 13.6 \%$ and $13.1 \%$ in Buea (South West Region) and highest values of $19.7 \%, 21.9 \%$ and $19.7 \%$ in Mora (Far North Region), respectively. The CF is highest in the North, Far North and Adamawa regions while it is lowest in the South and South West regions.

\section{Economic analysis}

The economic analysis undertaken in this paper consists of evaluating the simple payback periods and levelised costs of electricity generation from PV systems in Cameroon. It is assumed that the normalised electricity output from the PV systems would vary between 1053 and $1764 \mathrm{kWh} / \mathrm{kW}_{\mathrm{p}} / \mathrm{yr}$ depending on the location where they are installed. Annual electricity output is assumed to decrease by $0.5 \%$ over the service life of the PV system. The installed costs of the PV systems are considered to vary between 1500 and $2500 € / \mathrm{kW}_{\mathrm{p}}$. The analyses are based on grid connected commercial and industrial consumers with annual electricity demand greater than $800 \mathrm{kWh}$ with electricity purchase cost of $15.09 € \mathrm{c} / \mathrm{kWh}$.

It is assumed that the PV systems will be installed in premises with electricity loads that coincide with generation from PV systems. As a consequence, all the electricity generated by the PV systems would be used on-site with shortfalls imported from the grid. The PV systems are assumed to have a useful service life of

Table 4

Parameters used in the economic analysis.

\begin{tabular}{lll}
\hline Parameter & Value & Unit \\
\hline Annual electric energy generation & $1053-1764$ & $\mathrm{kWh} / \mathrm{kW} / \mathrm{yr}$ \\
Capital cost & $1500-2500$ & $€ / \mathrm{kW}_{\mathrm{p}}$ \\
Electricity price & 0.1509 & $€ / \mathrm{kWh}$ \\
System life & 30 & Years \\
Annual O\&M percentage of capital cost & 2 & $\%$ \\
Discount rate & 5 and 10 & $\%$ \\
Annual PV output degradation & 0.5 & $\%$ \\
\hline
\end{tabular}

30 years with annual operation and maintenance cost of $2 \%$ of the initial investment. $5 \%$ and $10 \%$ discount rates are used to compute the levelised cost of electricity generation. A summary of the parameters used in the economic analyses are shown in Table 4.

\section{Simple payback period}

The simple payback period is the period of time required for the profit or other benefits of an investment to equal the cost of the investment. For an investment in PV systems it would represent the time it takes for the cumulative annual investment to equal the initial investment. Fig. 2 shows the simple payback period against capital cost for PV systems installed in locations with annual electricity generation of 1053 and $1764 \mathrm{kWh} / \mathrm{kW}_{\mathrm{p}}$. It is seen that the simple payback period would vary between 5.6 and 9.4 years, 7.5 and 12.6 years, and 9.4 and 15.7 years for an installed cost of 1500,2000 and $2500 € / \mathrm{kW}_{\mathrm{p}}$, respectively in locations with annual electricity generation of 1764 and $1053 \mathrm{kWh} / \mathrm{kW}_{\mathrm{p}}$.

\section{Levelised cost of electricity}

Levelised cost of electricity (LCoE) is the most transparent consensus measure and remains a widely used tool for comparing the unit costs of different technologies over their economic life in modelling and policy discussions. It corresponds to the cost of an investor assuming the certainty of production costs and the stability of electricity prices. Thus, if the electricity price is equal to the levelised average lifetime costs, an investor would precisely breakeven on the project. The discount rate reflects the return on capital for an investor in the absence of specific market or technology risks. The discount rate and electricity price are assumed constant during the lifetime of the project under consideration while all electricity generated is assumed to be sold at the LCoE. LCoE is expressed as [22]:

$$
\mathrm{LCoE}=\frac{\operatorname{CAPEX}+\sum_{n=1}^{N} \operatorname{OPEX}_{n}(1+d)^{-n}}{\sum_{n=1}^{N} G_{n}(1+d)^{-n}}
$$

Fig. 3 shows the LCoE generation against capital costs for location with 1053 and $1764 \mathrm{kWh} / \mathrm{kW}_{\mathrm{p}} / \mathrm{yr}$ annual electricity generation, at $5 \%$ and $10 \%$ discount rates. It is seen that for a PV system

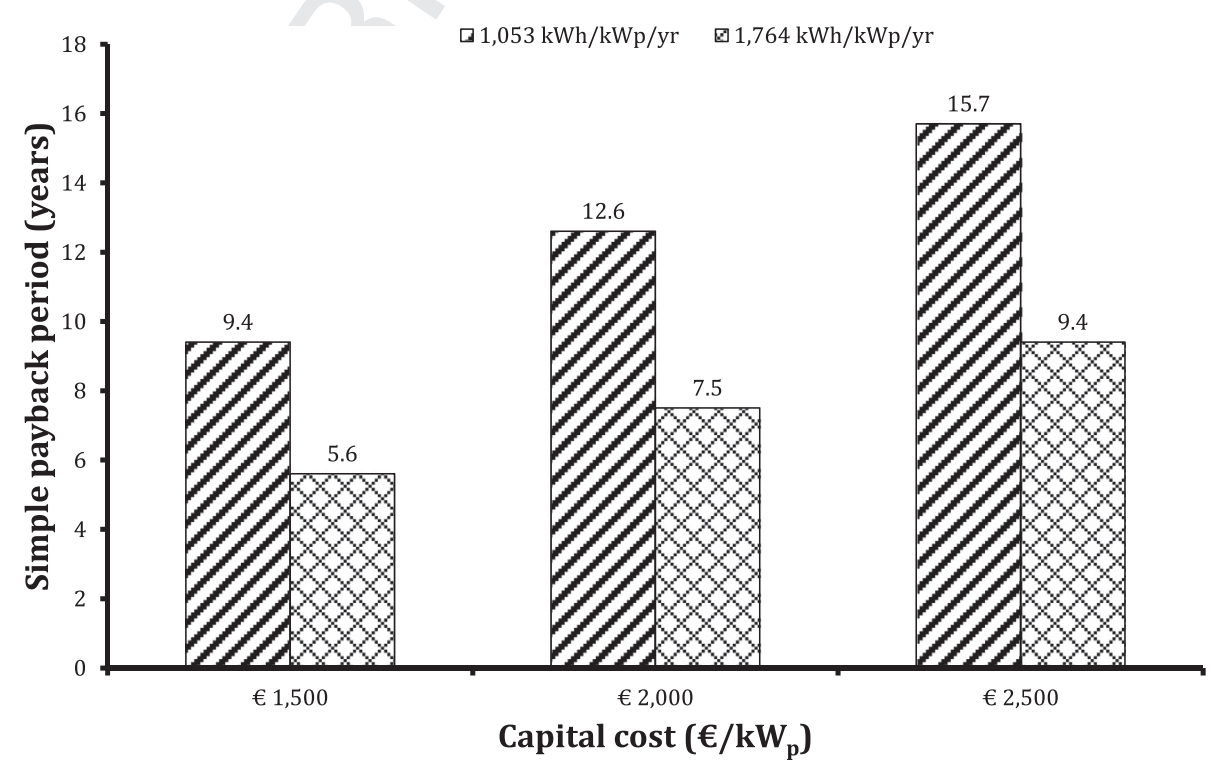

Fig. 2. Simple payback against capital cost for different annual electricity generation. 


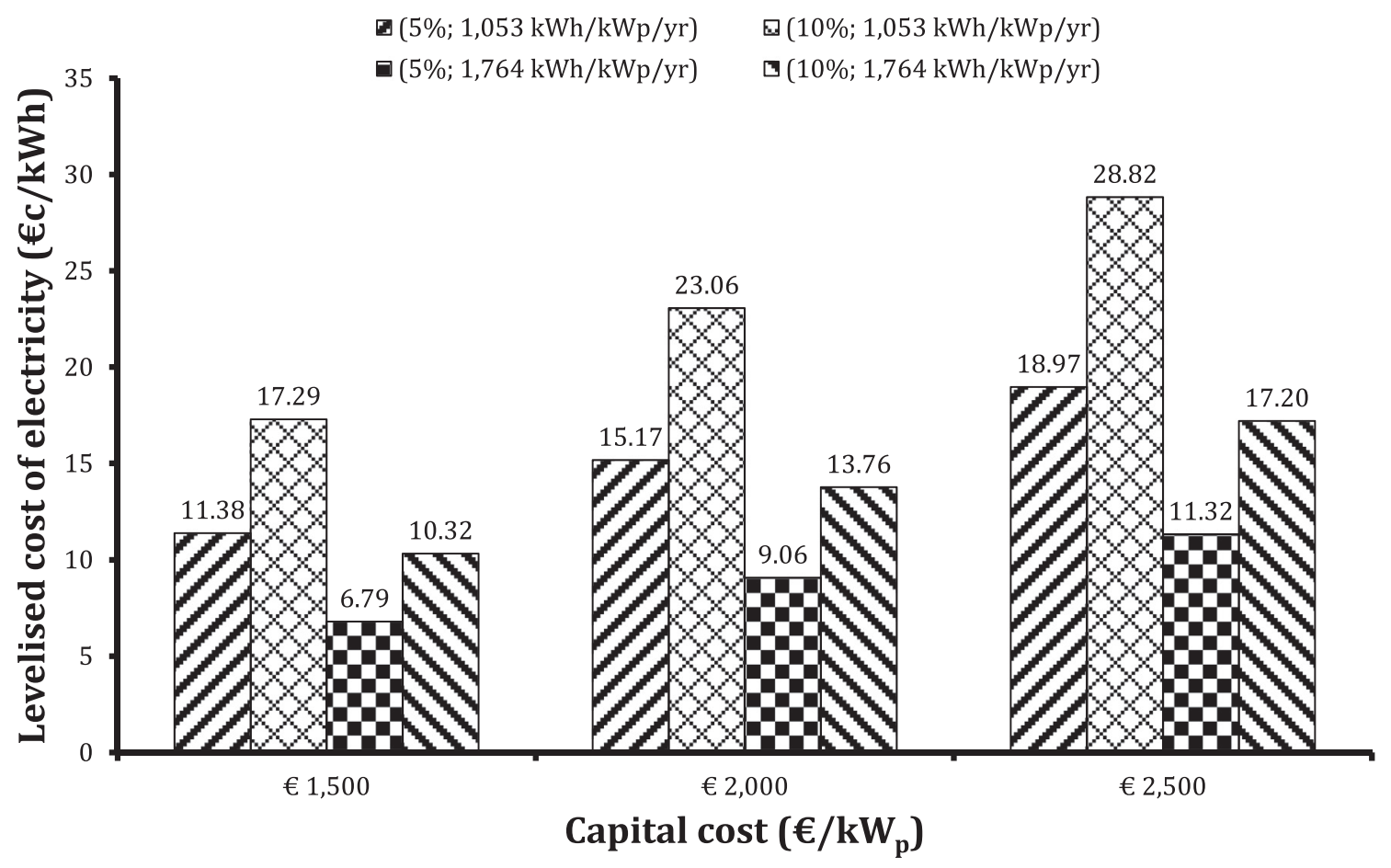

Fig. 3. Levelised cost of electricity generation against capital costs.

capital cost of $1500 € / \mathrm{kW}_{\mathrm{p}}$ the LCoE generation would vary between 11.38 and $1 \hat{7} .29 € \mathrm{ec} / \mathrm{kWh}$ for $5 \%$ and $10 \%$ discount rates in locations with annual electricity generation of $1053 \mathrm{kWh} / \mathrm{kW}_{\mathrm{p}} /$ yr. In locations with annual electricity generation of $1764 \mathrm{kWh} /$ $\mathrm{kW}_{\mathrm{p}} / \mathrm{yr}$ the LCoE generation would vary between $\widehat{6} .7 \hat{9}$ and $10.32 € \mathrm{c} / \mathrm{kWh}$ for $5 \%$ and $10 \%$ discount rates. For a PV system cap15.17 and $23.06 \hat{\epsilon} \mathrm{c} / \mathrm{kWh}$ for $5 \%$ and $10 \%$ discount rates in locations with annual electricity generation of $1053 \mathrm{kWh} / \mathrm{kW}_{\mathrm{p}} / \mathrm{yr}$. In locations with annual electricity generation of $1764 \mathrm{kWh} / \mathrm{kW}_{\mathrm{p}} / \mathrm{yr}$ the LCoE generation would vary between 9.06 and $13.76 € \mathrm{c} / \mathrm{kWh}$ for $5 \%$ and $10 \%$ discount rates. Finally, for a PV system capital cost of $2500 € / \mathrm{kW}_{\mathrm{p}}$ the LCoE generation would vary between 18.97 and $2 \hat{8} .8 \hat{2} € \mathrm{c} / \mathrm{kWh}$ for $5 \%$ and $10 \%$ discount rates in locations with annual electricity generation of $1053 \mathrm{kWh} / \mathrm{kW}_{\mathrm{p}} / \mathrm{yr}$. In locations with annual electricity generation of $17 \hat{6} 4 \mathrm{kWh} / \mathrm{kW}_{\mathrm{p}} / \mathrm{yr}$ the $\mathrm{LCoE}$ generation would vary between 11.32 and $17.20 € \mathrm{c} / \mathrm{kWh}$ for 5 and $10 \%$ discount rates.

\section{Conclusion}

Energy performance data of PV systems are of extreme importance to investors and project developers who are keen on setting up PV plants. The lack of reliable performance data for PV plants in locations such as Cameroon that are endowed with adequate solar resource has been a contributing factor towards the hesitance of both individuals, businesses, utility operators and independent power producers to invest in PV systems.

In this paper, the energy output, capacity factor and performance ratio of photovoltaic systems in 33 locations spread around ten regions in Cameroon were evaluated using monthly average daily global horizontal solar irradiation from long-term satellitederived data available in Solar GIS software. Optimally inclined PV modules with crystalline silicon, amorphous silicon and copper indium selenide were considered in the study. For all 33 locations amorphous silicon PV modules had the highest energy output, performance ratio and capacity factor followed by cupper indium selenide and crystalline silicon. ital cost of $2000 \mathrm{E} / \mathrm{kW}_{\mathrm{p}}$ the LCoE generation would vary between
The lowest average daily energy output was $3.13 \mathrm{kWh} / \mathrm{kW}_{\mathrm{p}}$ for c-Si PV modules installed in Buea (South West Region) while the highest average daily energy output was $5.25 \mathrm{kWh} / \mathrm{kW}_{\mathrm{p}}$ for a-Si PV modules installed in Mora (Far North Region). The PR varied between 74.0\% for c-Si PV modules installed in Mokolo (Far North Region) and $85.4 \%$ for a-Si PV modules installed in Banyo (Adamawa Region). The lowest CF was $13.1 \%$ for $\mathrm{c}-\mathrm{Si}$ and CIS PV modules in Buea (South West Region) while the highest CF was for a-Si PV modules installed in Mora (Far North Region).

The simple payback periods and levelised costs of electricity generation were computed for a range of capital costs, discount rates, normalised annual electricity generation and electricity tariff for consumers with annual electricity demand exceeding $800 \mathrm{kWh}$. Results from the economic evaluation revealed that a simple payback period of 5.6 years and levelised cost of electricity generation of $6.79 € c / k W h$ can be achieved in locations with annual electricity generation of $1764 \mathrm{kWh} / \mathrm{kW}_{\mathrm{p}}$ if the capital cost of the PV system is $1500 € / \mathrm{kW}_{\mathrm{p}}$ at a discount rate of $5 \%$. Alternatively, the simple paybầck period would be 15.7 years and the levelised cost of electricity generation $28.82 € \mathrm{c} / \mathrm{kWh}$ if the capital cost is $2500 € / \mathrm{kW}_{\mathrm{p}}$ at a discount rate of $10 \%$.

The return on investment would vary for different customers based on their location, investment cost, cost of capital (discount rate) and electricity tariff. With the levelised cost of electricity generation from PV competing favourably against the cost of grid supplied electricity under certain scenarios, the government of Cameroon should consider facilitating the deployment of PV in commercial buildings with loads that match PV generation. Such policies could include: exempting PV related equipment from custom duties until the market matures, providing low interest loans for the purchase of PV equipment, and providing capital cost grants in the form of tax breaks.

\section{References}

[1] Central Intelligence Agency (CIA). The world factbook; 2012. Available at: <https://www.cia.gov/library/publications/the-world-factbook/geos/ cm.html\#top>. 
SETA 33

ARTICLE IN PRESS

No. of Pages 9, Model 5G

29 October 2013

8

[2] African Development Fund. Project to strengthen and extend the electricity transmission and distribution networks in the Republic of Cameroon. Appraisal report, December 2009. Available at: <http://www.afdb.org/ fileadmin/uploads/afdb/Documents/Project-and-Operations/\%20Cameroon\%20-\%20AR\%20Electricity\%20Project\%20-\%5B1\%5D.pdf>.

[3] Government of Cameroon. Growth and employment strategy paper: reference framework for government action over the period 2010-2020; 2009. Available at: <http://www.imf.org/external/pubs/ft/scr/2010/cr10257.pdf>.

[4] Abanda FH. Renewable energy sources in Cameroon: potentials, benefits and enabling environment. Renew Sustain Energy Rev 2012;16(7):4557-62.

[5] Tchinda R, Kaptouom E. Situation dens energies nouvelles et renouvelables au Cameroun. Revue de l'Energie 1999;510:653-8.

[6] Tansi BN. An assessment of Cameroon's renewable energy resource and prospect for a sustainable economic development [NSc thesis]. Germany: Brandenburg Technical University; 2011.

[7] AES-SONEL. Annual report 2011. Available at: <http://investor.aes.com/ phoenix.zhtml?c=76149\&p=irol-reportsannual>.

[8] El Char L, Lamont LA, El Zein N. Review of photovoltaic technologies. Renew Sustain Energy Rev 2011;15(5):2165-75.

[9] Neij L. Cost development of future technologies for power generation - A study based on experience curves and complementary bottom-up assessments. Energy Policy 2008;36(6):2200-11.

Q4 [10] EPIA. Global market outlook for photovoltaic until 2016; 2012.

[11] SolarGIS Software. Available at: <http://solargis.info/pvplanner/>.

[12] Huld T, Müller R, Gambardella A. A new solar radiation database for estimating PV performance in Europe and Africa. Sol Energy 2012;86(6):1803-15.
[13] Gueymard CA, Wilcox SM. Assessment of spatial and temporal variability in the US solar resource from radiometric measurements and predictions from models using ground-based or satellite data. Sol Energy 2011;85(5):1068-84.

[14] Njomo D. Analyse de sensibilité dens systèmes héliothermiques dan un climat solaire tropical [Thèse d'Habilitation à Diriger does Recherches]. France: Energétique et Génie does Procédés, Université de Perpignan; 2003

[15] Njomo D, Wald L. Solar radiation retrieval in Cameroon from Meteosat satellite imagery using the Heliosat_2 method. Sci Technol Vic 2006;2(1):19-24.

[16] Ayompe LM, Duffy A, McCormack SJ, Conlon M. Measured performance of a 1.72 kilowatt rooftop grid connected photovoltaic system in Ireland. Energy Convers Manage 2011;52(2):816-25.

[17] Blaesser G. PV system measurements and monitoring the European experience. Sol Energy Mater Sol Cells 1997;47(1-4):167-76.

[18] Decker B, John U. Performance of 170 grid connected PV plants in northern Germany - Analysis of yields and optimization potentials. Sol Energy 1997;59(4-6):127-33.

[19] Eicker U. Solar technologies for buildings. John Wiley and Sons; 2003.

[20] Nakagami H, Ishihar O, Sakai K, Tanka A. Performance of residential PV system under actual field conditions in western part of Japan. In: International solar energy conference; 2003.

[21] Kymakis E, Kalykakis S, Papazoglou TM. Performance analysis of a grid connected photovoltaic park on the Island of Crete. Energy Convers Manage 2009;50(3):433-8.

[22] OECD, IEA and NEA. Projected costs of generating electricity. Paris; 2010.
509

510

511

512
513

514

515

516

517
518

519

520
521

522

523
524

525

526

528

529

530
531

532

533

Please cite this article in press as: Ayompe LM, Duffy A. An assessment of the energy generation potential of photovoltaic systems in Cameroon using sa-

tellite-derived solar radiation datasets. Sustainable Energy Technologies and Assessments (2013), http://dx.doi.org/10.1016/j.seta.2013.10.002 